\title{
Awareness of the Risks and Dangers of Social Networking: Exploration on Four Types of Malaysian Secondary Schools
}

\author{
THANG SIEW MING \\ HELP University, Kuala Lumpur \\ NG LAY SHI \\ Universiti Kebangsaan Malaysia \\ ADZUHAIDAH M. TAHA \\ Sekolah Seri Puteri Cyberjaya
}

\begin{abstract}
While social networking (SN) undoubtedly plays a vital role in the life of today's teenagers, its risks cannot be overlooked. SN can be a pervasive technology which can result in "risky behaviours". Issues linked to such behaviours have been investigated in a variety of contexts abroad (however, less so in the Malaysian context). The study aims at investigating Malaysian Secondary school students' awareness of the risks and dangers of SN. A quantitative approach involving a questionnaire survey was used to collect data. The questionnaire was designed to elicit information from the students regarding their awareness of the risks and dangers as well as abuse of the SN systems such as cyberbullying, harassment, sexting etc. The questionnaire was distributed to all available Form Four students from four selected schools in the Klang Valley and Selangor i.e. an urban school, a suburban school, a rural school and an elite school. The quantitative study was conducted on 562 students from the four schools. Descriptive and inferential statistics were used in analysing the data. The findings revealed that there was no rural-urban divide with regard to awareness of the risks and dangers involved in SN. Students in general seemed to be aware of the risks and dangers of SN. Likewise, there was no clear rural-urban divide regarding awareness of privacy issues. However, there was some ignorance regarding certain risks. For example, they were generally not aware that it was not possible to stay anonymous online. There were also some marked differences across school-types.
\end{abstract}

Keywords: Social networking, risks and dangers of social networking, rural-urban divide, different school types, teenagers.

\section{INTRODUCTION}

A social network system is a web-based service that allows individuals to build a public or semi-public profile in a system, share a connection, and view and cross-list their relationship with others in the system (Boyd \& Ellison, 2007). It will also allow fast and easy connections with friends, families, classmates, customers, and clients. It is now acknowledged that SN plays a major role in the life of today's teenagers and can be a pervasive technology that can result in "risky behaviour" which can be defined as a behaviour that potentially exposes them to harm, or a significant risk of harm. Some risky behaviour is normal and part of growing up but it can escalate to a harmful stage if it crosses normal behaviour (http://www.richmond.gov.uk/risky_behaviour_programme).

Privacy issues arising from $\mathrm{SN}$ include disclosure of embarrassing personal information, blackmailing through the use of photos found online, social scams and users' backlash against newly introduced features, cyberbullying, privacy issues and sexting. 
Children and adolescents are particularly vulnerable to such risks as they are less aware of the necessity for self-regulation (Bonneau \& Preibusch, 2010; O'Keefe \& Clarke-Pearson, 2011). These issues have caused concerns and led to increased efforts to comprehend the attitudes and behaviours of children and teenagers toward SN. Toktam Namayandeh Joorabchi et. al (2013) concurs with this. Many Malaysian youths have leveraged on the convenience of SN for their daily communication (Noor Ismawati et al., 2018) and this has led to heavy use of internet among them which may lead to exposure to the negative internet influences such as pornography, cyberbullying and sexting. However, research studies undertaken on Malaysian youth have also revealed positive influences of the use of the Internet and social media on them. Noor Azlin Bidin and Normah Mustaffa (2011) with Krish et al. (2009) found that blogs and discussion forums helped students gain self-confidence and learn in an online environment. Ng et al. (2018) with Thang and Ng (2020) further found that SN assists students' learning outside the classroom. Despite the positive effects of the Internet and social media, their potential dangers cannot be ignored and must be identified and addressed.

This project aims at exploring the effects arising from the use of such social media apps by Malaysian secondary school students for SN purposes. This project is a direct result of the desire to investigate to what extent SN has invaded the privacy of Malaysian teenagers. It is particularly interesting to find out the attitudes and behaviours of Malaysian teenagers toward SN and the degree they are concerned with the risks involved and how they manage these risks. There are numerous studies on these issues such as by Berkman and Shumway (2003), Debatin et al. (2009), Cocking and Matthews (2000), lachello and Hong (2007) and Tavani with Grodzinsky (2002). For instance, Debatin et al. (2009) conducted a study at a large university in Midwestern United States. Their study revealed that most of the participants claimed to understand privacy issues, yet reported uploading large amounts of personal information. The participants also believed that risks to privacy invasion were more ascribed to others than to themselves. There are very few such studies in the Malaysian context, especially in the secondary school context. This research aims to address this gap by reporting on the findings derived from secondary students from four types of schools: urban, suburban, rural and elite. The research objective of this study is to determine the awareness of the risks and dangers related to $\mathrm{SN}$ among students from different home backgrounds and from two different age groups. The following research questions were designed in response to the above objective:

(a) Are the students from the four schools aware of the risks and dangers of SN?

(b) Are there any differences in awareness among these students?

\section{LITERATURE REVIEW}

\section{a. Risks of SN}

The risks investigated by this study will be described in this section.

\section{Cyberbullying}

In this study, cyberbullying is defined as using an electronic version of contact to carry out deliberate hostile action against victims who do not have the means to protect themselves (Smith et al., 2006). This includes sending threatening, harassing or humiliating messages to them. It is common among teenagers and can result in severe emotional distress and psychosocial outcomes such as depression, severe isolation anxiety, and even suicide just 
days after reading hurtful comments (Cowie, 2013; Hinduja \& Patchin, 2010; Schenk \& Fremouw, 2012). In reference to suicidal attempts, Hinduja and Patchin (2010) reported that $20 \%$ of their respondents were seriously thinking of attempting suicide and it was twice more likely to happen among cyberbullying victims than those who were not victims.

\section{Texting/Media Sharing}

Texting too can be an instrument of bullying or humiliation. An image or video that is shameful or hurtful can in a blink of an eye exchange hands or be uploaded to a video sharing website. An extensive variety of social media tools are accessible for viewing and sharing by mediasharing sites, such as YouTube. These media-sharing sites are easily available and can be accessed through desktop and mobile devices. Lenhart et al. (2010) discovered although teens generally use messages responsibly, there have been many incidences of misuse. Not all of these incidences resulted from malicious intent. In many cases, they were sent carelessly without considering the receivers' reactions and subsequently leading to regret on the part of the senders but that would be too late as the damage had already been done.

\section{Sexting}

Sexting has been defined as 'exchanges of sexual messages or images' as well as 'the creating, sharing and forwarding of sexually suggestive nude or nearly nude images' through mobile phones and/or the internet (Lenhart, 2009; Lohmann, 2012). A survey undertaken in the USA revealed that $20 \%$ of teens had at some time sent or posted nude or semi-nude photographs or videos of themselves (National Campaign to Prevent Teen and Unplanned Pregnancy, 2008). Another survey undertaken at a private high school in the southwest USA found that $20 \%$ of the boys and girls in the survey had sent cell phone pictures that were sexually explicit and about $33 \%$ girls and $50 \%$ boys had at one time or another received such pictures (Strassberg et al., 2013).

\section{Online Sexual Solicitation and Predation}

Sexual solicitations can be defined as "request to engage in sexual activities or sexual talk or provide personal sexual information that is unwanted or when made by an adult to a young person with or without his/her consent" (Davidson \& Gottschalk, 2010; Mitchell et al., 2014.). Wolak et al. (2006) found that the sexual solicitation rate for teens in the USA is estimated at between $13-19 \%$ and Cox (2007) discovered that $16 \%$ of teens using the internet said they have considered meeting someone they have only talked to online and $8 \%$ have done so. Most internet-initiated sex crime offenders are adult men. They would use Internet communications to meet and build intimate relationships with their victims. In most cases, the victims are not aware that they were communicating with adults (Wolak et al., 2008).

\section{Exposure to Illegal Content and Privacy Violation Communication}

The rise of digital technology has made the young generation more exposed to illegal and problematic Internet-based content such as violent media materials and pornographic content that is intended for adults' consumption. Youth also commonly encounter phonography online. It was reported that almost $13 \%$ of U.S. youth in 2000 and $17 \%$ in 2005 reported seeing "pictures that were violent" online (Wolak et al., 2006). On top of that 31\% of youth in the UK reported seeing "violent or gruesome material online" (Livingstone \& Bober, 2004). 
Many previous studies have revealed that teenagers, while online, care about their privacy and will carry out privacy protecting measures to keep away from risks (Youn, 2009; Cox, 2007). Such measures include modifying their online profiles from "public" to "private access", not providing information regarding their own identity, providing inaccurate information or staying away from dubious websites (Youn, 2009). Nevertheless, Cox (2007) surprisingly revealed that many youths do not bother to read websites' privacy policies or are careless in revealing their details to third parties. It seems that these youths are more worried about communicating with strangers and less wary about posting personal information and photos online to a public profile such as Facebook.

\section{b. The Malaysian Scene}

There are two recent studies undertaken on cyberbullying in the Malaysian context of Malaysian youths. The first study was undertaken by Sarina Yusuf et al. (2018). It was a quantitative study conducted on 378 students between the ages of 9 and 16 from eight schools in Selangor. The results of the study showed that 3.9\% of the respondents had been threatened online, $20.8 \%$ had seen inappropriate materials at least once posted online and $14.5 \%$ of the respondents had seen people committing obscene acts online. The study further revealed that only $11.1 \%$ of the respondents had suffered the humiliation of being expelled from an online group and $4.2 \%$ of them had been asked by someone to share pictures or videos of their private parts online. The overall results of the study suggested that the majority of the respondents had experienced mild forms of cyberbullying at least once within the past year indicating that serious incidents of cyberbullying were rare and far between.

This second study undertaken by Balakrishnan (2015) investigated the extent of cyberbullying experienced by 393 young adults between the ages of 17 and 30 years old. The questionnaire survey took into consideration the views of cyberbullies and cyber-victims. The study showed that cyberbullying was still prevalent after schooling. No significant gender differences were found but there were more cyberbullies and cyber-victims among female respondents. Also, younger respondents were found to engage more in cyberbullying activities (i.e. victims and perpetrators) than the older respondents. The findings further revealed that there were more victims and bullies among those who spent more time on the Internet (that is at least two to 5 hours daily). Finally, the findings of the study revealed a tendency for cyber-victims to become cyberbullies, and vice versa which is indeed a disturbing finding.

Finally, there is a 2014 report published by The Malaysian Ministry of Education in collaboration with DiGi Telecommunications, Malaysian Communications and Multimedia Commission (MCMC) and Cyber Security Malaysia on the use of the Internet by Malaysian youths (Digi Telecommunication, 2014). The report based on a national survey undertaken in 2013 on 13, 945 students ranging in age from 7 to 19 years old yielded some illuminating findings:

(i) Although more than $80 \%$ of the students agreed that practising safe behaviour online was important, about $40 \%$ of them did not know how to protect themselves online. This awareness was also not accompanied by positive actions and safer behaviours. The findings further revealed that those below 15 years of age were more at risk than those of 16-19 years old. 
(ii) $83 \%$ of the students did not use a variety of measures to protect themselves while using the Internet with $30 \%$ using one or zero method. Surprisingly $52 \%$ felt safe using the Internet. There was little difference between male and female students with regard to the actions they took to protect themselves on the Internet. This applied to both urban and rural students.

(iii) The main concerns among these students were exposure of identity, not knowing the identity of those they were interacting with and invasion of privacy.

(iv) There were incidents of cyberbullying in all age categories with $25 \%$ claiming that they had been bullied at least once. $45 \%$ said that they would reveal their negative cyberbullying experiences to their parents, friends and siblings and very few said they would seek help from their teachers, counsellors and online public support system.

The report proposed the development of a programme to strengthen students' awareness of the technological and social issues related to the use of the Internet especially issues regarding dangers and risks involved. The establishment of CyberSAFE (Cyber Security Awareness for Everyone) under the Malaysia Ministry of Science, Technology of Innovation was part of Malaysia's efforts to overcome the variety of issues related to the Internet in this rapidly advancing digital society.

With these studies and reports as the background, the current study undertaken in 2016 sought to find out to what extent Malaysian secondary school students' attitudes and behaviours have changed as a result of the measures undertaken by MCMC to solve the issues involved particularly on issues of risks and dangers.

\section{RESEARCH METHODOLOGY}

Context of the Project

The students for this project were derived from four types of secondary schools from the Klang Valley and Selangor in Malaysia i.e. an urban school, a suburban school, a rural school and lastly an elite school. Table 1 summarised the characteristics of the students in the four schools. As shown in Table 1, the students from the four different types of schools have different home backgrounds. Parents of students from the urban school and the elite school are more affluent, hence these students will be the ones with the highest exposure to internet facilities, followed by the suburban school students and the last, the rural school students. Statista.com (2019) reported that teenagers living in urban areas had better access to internet facilities than those living in rural areas and as mentioned earlier, higher exposure to the Internet and social media may lead to greater risks and dangers. Hence, this study is interested to find out to what extent different home backgrounds affect these students' awareness of the risks and dangers of SN.

Table 1: Characteristics of the students from the four schools

\begin{tabular}{cclcl}
\hline Characteristic & Urban school & Suburban school & \multicolumn{1}{c}{ Rural school } & Elite school \\
\hline Location of school & Near Kuala Lumpur (KL) & In Putrajaya & $\begin{array}{l}\text { In a small town } 30 \mathrm{~km} \\
\text { from KL }\end{array}$ & In Cyberjaya \\
Type of school & Co-education school & $\begin{array}{l}\text { Co-education } \\
\text { school }\end{array}$ & $\begin{array}{l}\text { Co-education } \\
\text { school }\end{array}$ & Girls' school \\
\hline
\end{tabular}




\begin{tabular}{|c|c|c|c|c|}
\hline $\begin{array}{l}\text { Medium of } \\
\text { instruction }\end{array}$ & $\begin{array}{l}\text { Mandarin except for } \\
\text { English and Bahasa } \\
\text { Malaysia }\end{array}$ & $\begin{array}{l}\text { Bahasa Malaysia } \\
\text { except for } \\
\text { English }\end{array}$ & $\begin{array}{l}\text { Bahasa Malaysia } \\
\text { except for English }\end{array}$ & $\begin{array}{l}\text { Bahasa Malaysia } \\
\text { except for } \\
\text { English }\end{array}$ \\
\hline Ethnic origin & All Chinese & All Malay & $\begin{array}{l}\text { Malay, Chinese, } \\
\text { Indians \& others }\end{array}$ & All Malay \\
\hline Previous school & $\begin{array}{l}\text { National-type Chinese } \\
\text { school }\end{array}$ & $\begin{array}{l}\text { National primary } \\
\text { school }\end{array}$ & $\begin{array}{l}\text { National primary } \\
\text { school, National-type } \\
\text { Chinese school \& } \\
\text { National-type } \\
\text { Tamil school }\end{array}$ & $\begin{array}{l}\text { National primary } \\
\text { school \& private } \\
\text { school }\end{array}$ \\
\hline $\begin{array}{l}\text { Performance in } \\
\text { PT3 (Form } 3 \\
\text { Assessment } \\
\text { Exam) }\end{array}$ & High to average & $\begin{array}{l}\text { High to below } \\
\text { average }\end{array}$ & More low than high & All high \\
\hline $\begin{array}{l}\text { Language spoken } \\
\text { at home }\end{array}$ & Mainly Chinese & Malay & Mother tongue & English \& Malay \\
\hline $\begin{array}{l}\text { Home } \\
\text { background }\end{array}$ & $\begin{array}{l}\text { Middle to upper middle } \\
\text { class; Parents are } \\
\text { business personnel, white } \\
\text { collar workers/ } \\
\text { professionals }\end{array}$ & $\begin{array}{l}\text { Middle income; } \\
\text { Parents mostly } \\
\text { government } \\
\text { servants }\end{array}$ & $\begin{array}{l}\text { Middle to low } \\
\text { income; Parents } \\
\text { mostly blue collar } \\
\text { workers }\end{array}$ & $\begin{array}{l}\text { Upper middle } \\
\text { class; Parents } \\
\text { are professional } \\
\text { or business } \\
\text { personnel }\end{array}$ \\
\hline
\end{tabular}

\section{RESEARCH DESIGN}

This study was conducted using quantitative approaches that employed a questionnaire survey to elicit information regarding students' use of SN systems as well as to identify their behaviours towards the risks and dangers of SN.

\section{Research Instrument}

The quantitative instrument has three sections:

a) Section A elicits demographic information of the students.

b) Section B elicits information regarding students' $\mathrm{SN}$ patterns and behaviours which include investigating their behaviours towards SN, awareness of risks as well as awareness of abuse of the $\mathrm{SN}$ systems such as cyberbullying, harassment, sexting etc.

\section{Research Procedures}

The convenience sampling approach was used. The questionnaire was distributed to all available Form Four students from the selected four schools. Only Form four students were selected as it was not possible to obtain permission to conduct the research on examination classes (i.e. Form Three and Form five students).

\section{Baseline Data}

\section{RESEARCH FINDINGS}

The base-data were derived from Section A and Section B of the questionnaires collected from students from all four schools. The overall breakdown of students according to age groups, genders, ethnic origins and types of schools are given in Table 2. As can be seen from Table 2, 
there is a good representation of subjects for each category and a good reflection of the school population in Malaysia.

Table 2: Breakdown of students from all four schools

\begin{tabular}{lcccccccccccc}
\hline \multicolumn{1}{c}{ School } & $\mathbf{F}$ & $\%$ & $\mathbf{M}$ & $\%$ & Malay & $\%$ & Chinese & $\%$ & Others & $\%$ & Total & (\%) \\
\hline Urban & 53 & 46.9 & 60 & 53.1 & 0 & 0 & 113 & 100 & 0 & 0 & 113 & 20.1 \\
Suburban & 69 & 46.3 & 80 & 53.7 & 149 & 100 & 0 & 0 & 0 & 0 & 149 & 26.5 \\
Rural & 92 & 61.3 & 58 & 38.7 & 91 & 60.7 & 39 & 26 & 20 & 13.3 & 150 & 26.7 \\
Elite & 150 & 41.2 & -- & 100 & 150 & 100 & 0 & 0 & 0 & 0 & 150 & 26.7 \\
Total & 364 & 64.8 & 198 & 35.2 & 390 & 69.4 & 152 & 27 & 20 & 3.6 & 562 & 100 \\
\hline
\end{tabular}

\section{Descriptive Data Analysis}

The descriptive data involve comparing of mean scores according to the various categories.

\section{a. Category I: Comparison of Behaviour According to Risks Involved}

Table 3: Comparison across schools for age 16 students

\begin{tabular}{|c|c|c|c|c|c|}
\hline No* & Students & Urban & Suburban & Rural & Elite \\
\hline
\end{tabular}

\begin{tabular}{|c|c|c|c|c|c|c|c|c|c|}
\hline 37 & $\begin{array}{l}\text { Smart phone navigation allow others to locate } \\
\text { your position }\end{array}$ & 113 & 3.41 & 146 & 3.24 & 145 & 3.13 & 150 & 3.39 \\
\hline 45 & $\begin{array}{l}\text { Meet up with someone you get to know on SN } \\
\text { sites }\end{array}$ & 112 & 3.39 & 148 & 2.41 & 149 & 2.46 & 150 & 3.22 \\
\hline 38 & Trust information on SN sites & 113 & 2.74 & 149 & 3.02 & 147 & 2.93 & 150 & 2.93 \\
\hline 9 & Like to post selfies on SN & 113 & 3.25 & 149 & 3.09 & 147 & 2.82 & 150 & 2.92 \\
\hline 43 & $\begin{array}{l}\text { Respond to new friends/strangers' call messages } \\
\text { on SN sites }\end{array}$ & 112 & 2.50 & 149 & 2.74 & 148 & 2.45 & 150 & 2.56 \\
\hline 44 & $\begin{array}{l}\text { Accept if a stranger wants to be your friend on } \\
\text { SN sites }\end{array}$ & 112 & 2.77 & 149 & 2.61 & 146 & 2.23 & 150 & 2.67 \\
\hline 41 & $\begin{array}{l}\text { Message suddenly appear asking for username \& } \\
\text { password while on SN }\end{array}$ & 113 & 2.22 & 147 & 2.33 & 148 & 2.35 & 149 & 2.46 \\
\hline 40 & $\begin{array}{l}\text { What do you think of people who post selfies } \\
\text { online? }\end{array}$ & 112 & 2.67 & 149 & 2.66 & 148 & 2.20 & 143 & 2.40 \\
\hline
\end{tabular}

The range for category $\mathrm{I}$ is from 1 to 4 . Mean scores approaching 2.5 and below are taken to indicate a lack of awareness of risky behaviour or a tendency to indulge in risky behaviour. As shown in Table 3, the means scores of items 37, 38 and 39 are all above 2.5 which means all four groups of students are aware of these risks. However it appears that all four groups of students also display some risky behaviour. All four types of students 
display the risky tendency of responding to messages asking for user name and passwords (item 41). Regarding befriending strangers, elite students will not befriend strangers they meet online (items 45, $43 \& 44$ ). However, the rest will do so to a certain extent. Suburban and rural students indicate they may even meet them personally (item 45 ). The mean scores of elite students are all above 2.5 for all items except for item 41 which strongly suggests that on the whole, the elite students display the least risky behaviour. However, only elite and rural students view posting selfies online as not risky (item 40 ).

b. Category II: Comparison of Tendency to Act towards Cyberbullying

Table 4: Comparison across schools for age 16 students

\begin{tabular}{llllllllllll}
\hline No* & \multicolumn{1}{c}{ Students } & Urban & Suburban & Rural & Elite \\
\hline & & No. Mean & No. Mean & No. & Mean & No. Mean \\
47 & $\begin{array}{l}\text { Act when witness someone } \\
\text { continuous harassment messages }\end{array}$ & receiving & 113 & 2.65 & 147 & 3.15 & 147 & 2.92 & 150 & 3.11 \\
$46 \quad \begin{array}{l}\text { Act if receive negative comments or posts with } \\
\text { threatening messages }\end{array}$ & 112 & 1.94 & 147 & 2.31 & 148 & 2.03 & 150 & 2.33 \\
\hline
\end{tabular}

The range for category II is also from 1 to 4 . Mean scores approaching 2.5 and below are taken to indicate a lower tendency to act against cyberbullying. As displayed in Table 4, the mean scores of all four types of students are above 2.5 for item 47, which is an indication of the students' awareness that harassment is a wrongful act and that they are willing to act if they witness it. However, in the case of doing something if they themselves are harassed online, none of them seem inclined to take action (item 46).

c. Category III: Comparison of Awareness of What Harrassment and Cyberbullying Mean

Table 5: Comparison across schools for age 16 students

\begin{tabular}{llllllllll}
\hline Students Age 16 & Urban & Suburban & \multicolumn{2}{c}{ Rural } & Elite \\
\hline & No. Mean & No. Mean & No. Mean & No. Mean \\
49 & $\begin{array}{l}\text { Do you have the right to post pictures that you } \\
\text { took of your friends online? }\end{array}$ & 113 & 3.02 & 148 & 3.15 & 147 & 2.74 & 150 & 3.19 \\
48 & $\begin{array}{l}\text { Do you know the consequences of bullying or } \\
\text { harassing someone online? }\end{array}$ & 112 & 2.85 & 147 & 2.95 & 147 & 2.99 & 149 & 3.34 \\
\hline
\end{tabular}

The range for category III is from 1 to 4 . Mean scores approaching 2.5 and below are taken to indicate a lack of awareness of the danger of harassment and cyberbullying. As shown in Table 5, the mean scores of all the four types of students are all above 2.5 which shows awareness of what harassment and cyberbullying entail and the consequences. 
d. Category IV: Ranking According to Awareness of the Danger of Internet

Table 6: Comparison across schools for age 16 students

\begin{tabular}{lllllllllllll}
\hline No* & Students Age 16 & Urban & \multicolumn{2}{c}{ Suburban } & \multicolumn{2}{c}{ Rural } & \multicolumn{2}{c}{ Elite } \\
\hline 51 & No. Mean & No. & Mean & No. & Mean & No. Mean \\
& $\begin{array}{l}\text { Can you delete pictures or comments once } \\
\text { you posted them online? }\end{array}$ & 113 & 3.07 & 149 & 3.10 & 148 & 3.24 & 153 & 2.97 \\
57 & $\begin{array}{l}\text { Where are most of your online data } \\
\text { stored? (for instance your vacation } \\
\text { photos) }\end{array}$ & 112 & 3.28 & 148 & 2.93 & 147 & 2.86 & 152 & 2.72 \\
50 & Can you remain anonymous online & 113 & 1.60 & 147 & 1.81 & 147 & 1.92 & 153 & 1.68 \\
\hline
\end{tabular}

The range for category IV is from 1 to 4 for items 51 and 57. Mean scores approaching 2.5 and below are taken to indicate a low awareness of the danger of the Internet. The range for item 50 is from 1 to 3. Mean scores approaching 2.2 and below are taken to indicate a low awareness of the danger of the Internet. Table 6 demonstrates that generally, students from the four types of schools are aware that internet is dangerous in that things posted cannot be deleted easily (item 51) and that it is not safe to store things online (57) but they still believe that it is possible to stay anonymous online if they so prefer (Item 50).

e. Category V: Comparison According to Awareness of Danger of Sexting or Exposure to Indecent Materials

Table 7: Comparison across schools for age 16 students

\begin{tabular}{|c|c|c|c|c|c|c|c|c|c|}
\hline \multirow[t]{2}{*}{ No* } & \multirow[t]{2}{*}{ Students Age 16} & \multicolumn{2}{|c|}{ Urban } & \multicolumn{2}{|c|}{ Suburban } & \multicolumn{2}{|c|}{ Rural } & \multicolumn{2}{|c|}{ Elite } \\
\hline & & No. & Mean & No. & Mean & No. & Mean & No. & Mean \\
\hline 52 & $\begin{array}{l}\text { Nothing wrong for me to download indecent } \\
\text { materials shared in the SN sites/ applications. }\end{array}$ & 113 & 2.49 & 148 & 2.78 & 147 & 2.65 & 150 & 2.95 \\
\hline 54 & $\begin{array}{l}\text { Nothing wrong in sending sexually-suggestive } \\
\text { messages/pictures through SN sites to my } \\
\text { friends/BF/GF. }\end{array}$ & 113 & 2.35 & 146 & 2.64 & 148 & 2.47 & 150 & 2.90 \\
\hline
\end{tabular}

The range for category $V$ is also from 1 to 3 . Mean scores approaching 2.2 and below are taken to indicate a lack of awareness of the danger of sexting and exposure to indecent materials. As seen in Table 7, generally the students from all types of schools are aware of the danger of downloading indecent materials (item 52) and sending sexually suggestive materials (item 54). 
e. Category VI: Comparison According to Exposure to Sexting Behaviour

Table 8: Comparison across schools for age 16 students

\begin{tabular}{|c|c|c|c|c|c|c|c|c|c|}
\hline \multirow[t]{2}{*}{ No* } & \multirow[t]{2}{*}{ Students Age 16} & \multicolumn{2}{|c|}{ Urban } & \multicolumn{2}{|c|}{ Suburban } & \multicolumn{2}{|c|}{ Rural } & \multicolumn{2}{|c|}{ Elite } \\
\hline & & No. & Mean & No. & Mean & No. & Mean & No. & Mean \\
\hline 53 & $\begin{array}{l}\text { I have seen my friend or someone I know sexting } \\
\text { (sharing pictures, videos or comments of a } \\
\text { sexual nature) to his or her BF/GF (1-3) }\end{array}$ & 113 & 2.35 & 149 & 2.59 & 149 & 2.18 & 150 & 2.69 \\
\hline 55 & $\begin{array}{l}\text { I have seen my friends or someone I know } \\
\text { download indecent materials shared in the SN } \\
\text { sites (1-3). }\end{array}$ & 113 & 2.32 & 149 & 2.06 & 147 & 2.23 & 150 & 2.43 \\
\hline 56 & $\begin{array}{l}\text { Have you been talked into sexting (sharing } \\
\text { pictures, videos or comments of a sexual nature) } \\
\text { by your friends/BF/GF (1-4) }\end{array}$ & 113 & 2.51 & 149 & 1.93 & 149 & 2.52 & 150 & 2.67 \\
\hline
\end{tabular}

The range for category $\mathrm{VI}$ is from 1 to 3 for items 53 and 55, which are classified as indirect sexting. Hence mean scores approaching 2.2 and below are taken to indicate possible exposure to sexting. The range for item 56 , which is classified as indirect sexting is from 1 to 4. Thus, mean score approaching 2.5 and below are taken to indicate possible exposure to sexting. Elite students are least exposed to sexting directly and indirectly as shown in Table 8. Rural students are the most vulnerable as they are exposed to both direct and indirect sexting (items $53 \& 56$ ). Both urban and suburban students have more exposure to direct sexting (item 56) and less to indirect sexting (items 53 \& 55).

\section{Inferential Data Analysis}

Inferential statistical data analysis was undertaken using ANOVA to compare the mean scores of the four types of students. A cut-off of $5 \%$ that is $p$-value of less than 0.05 was used to identify differences in mean scores that are statistically significant. The general rule to follow in interpreting the findings is that the mean scores of the highlighted items are significantly higher than the mean scores of the underlined (non-highlighted) items. The findings are tabulated into the two following categories:

Category $A$ - Behaviour according to awareness of risks involved

Category B - Awareness of danger of SN which covers Category II to VI of the descriptive statistics

Category A: Behaviour According to Awareness of Risks Involved

Table 9: Comparison across schools for age 16 students

\begin{tabular}{|c|c|c|c|c|c|}
\hline No* & Students & School Type & No & Mean & SD \\
\hline \multirow[t]{4}{*}{39} & Like to post selfies on SN & Suburban & 149 & 3.09 & 697 \\
\hline & & Elite & 150 & $\underline{2.92}$ & .728 \\
\hline & & Rural & 147 & $\underline{2.82}$ & .850 \\
\hline & & Urban & 113 & 3.25 & .701 \\
\hline
\end{tabular}




\begin{tabular}{|c|c|c|c|}
\hline Suburban & 149 & 2.66 & 1.217 \\
\hline Elite & 143 & 2.40 & 1.001 \\
\hline Rural & 148 & $\underline{2.20}$ & 1.069 \\
\hline Urban & 112 & 2.67 & 1.158 \\
\hline Suburban & 149 & 2.61 & 1.113 \\
\hline Elite & 150 & 2.67 & 1.013 \\
\hline Rural & 146 & $\underline{2.23}$ & 1.029 \\
\hline Urban & 112 & 2.77 & 1.115 \\
\hline Suburban & 148 & $\underline{2.41}$ & 1.183 \\
\hline Elite & 150 & 3.22 & .947 \\
\hline Rural & 149 & $\underline{2.46}$ & 1.205 \\
\hline Urban & 112 & 3.39 & .924 \\
\hline Suburban & 149 & 3.02 & .442 \\
\hline Elite & 150 & 2.93 & .412 \\
\hline Rural School & 147 & 2.93 & .525 \\
\hline Urban & 113 & $\underline{2.74}$ & .514 \\
\hline
\end{tabular}

A comparing of mean scores of the items indicates that the suburban and urban students are significantly more aware of the risks of posting selfies than the rural and elite students (as shown in Table 9). Likewise, they are more aware that people posting selfies online are putting themselves to greater risks than urban students. With regard to befriending and meeting strangers online, the elite and urban students are significantly more aware of the danger of this practice than the rural students. However, urban students seem to be significantly less wary of trusting information online than the other students.

Category B - Awareness of Danger of SN Which Covers Category II to VI of the Descriptive Statistics

Table 10: Comparison across school for age 16 students

\begin{tabular}{llllll}
\hline & \multicolumn{1}{c}{ Students } & School & No. & Mean & SD \\
\hline $46 \quad \begin{array}{l}\text { Act if you receive negative comments or posts with } \\
\text { threatening messages }\end{array}$ & Suburban & 147 & 2.31 & 1.339 \\
& & Elite & 150 & 2.33 & 1.384 \\
& Rural & 148 & $\underline{2.03}$ & 1.318 \\
& Urban & 112 & $\underline{1.94}$ & 1.393 \\
\hline
\end{tabular}




\begin{tabular}{|c|c|c|c|c|c|}
\hline \multirow[t]{4}{*}{47} & $\begin{array}{l}\text { Act when witness someone receiving continuous harassment } \\
\text { messages }\end{array}$ & Suburban & 147 & 3.15 & 1.016 \\
\hline & & Elite & 150 & 3.11 & 1.050 \\
\hline & & Rural & 147 & 2.92 & 1.219 \\
\hline & & Urban & 113 & $\underline{2.65}$ & 1.017 \\
\hline \multirow[t]{4}{*}{48} & $\begin{array}{l}\text { Do you know the consequences of bullying or harassing } \\
\text { someone online? }\end{array}$ & Suburban & 147 & $\underline{2.95}$ & 1.221 \\
\hline & & Elite & 149 & 3.34 & .963 \\
\hline & & Rural & 147 & 2.99 & 1.205 \\
\hline & & Urban KL & 112 & $\underline{2.85}$ & 1.125 \\
\hline \multirow[t]{4}{*}{50} & Can you remain anonymous online? & Suburban & 147 & 1.81 & .855 \\
\hline & & Elite & 153 & 1.68 & .802 \\
\hline & & Rural & 147 & 1.92 & .864 \\
\hline & & Urban & 113 & 1.60 & .797 \\
\hline \multirow[t]{4}{*}{51} & $\begin{array}{l}\text { Can you delete pictures or comments once you posted them } \\
\text { online? }\end{array}$ & Suburban & 149 & 3.10 & 1.057 \\
\hline & & Elite & 153 & $\underline{2.97}$ & 1.329 \\
\hline & & Rural & 148 & 3.24 & 1.033 \\
\hline & & Urban & 113 & 3.07 & 1.186 \\
\hline \multirow[t]{4}{*}{57} & $\begin{array}{l}\text { Where are most of your online data stored? (for instance your } \\
\text { vacation photos) }\end{array}$ & Suburban & 147 & 1.81 & 1.155 \\
\hline & & Elite & 152 & $\underline{2.72}$ & 1.014 \\
\hline & & Rural & 147 & $\underline{1.92}$ & 1.212 \\
\hline & & Urban & 112 & 3.28 & .851 \\
\hline \multirow[t]{4}{*}{54} & Nothing wrong in sending sexually-suggestive & Suburban & 146 & $\underline{2.64}$ & .663 \\
\hline & & Elite & 150 & 2.90 & .279 \\
\hline & & Rural & 148 & 2.47 & .760 \\
\hline & & Urban & 113 & $\underline{2.35}$ & .667 \\
\hline \multirow[t]{4}{*}{52} & $\begin{array}{l}\text { Nothing wrong to download indecent materials shared in the } \\
\text { SN sites. }\end{array}$ & Suburban & 148 & 2.78 & .566 \\
\hline & & Elite & 150 & 2.95 & .380 \\
\hline & & Rural & 147 & $\underline{2.65}$ & .637 \\
\hline & & Urban & 113 & 2.49 & .696 \\
\hline
\end{tabular}


Table 10 indicates that the pattern for students is rather mixed. With regard to harassment and cyberbullying, all show willingness to act with the suburban and elite students showing significantly more willingness to act than the other groups. In addition to that the elite students are significantly more aware of the consequences of bullying than the other groups. Regarding safety such as deleting pictures permanently online, the awareness among all students are reasonably high but elite students significantly show the least awareness. As far as the risks involved storing data online, the urban students are significantly most aware whereas all four groups show a lack of awareness with regard to remaining anonymous, with urban students being significantly least aware. As far as sending sexual messages online and downloading indecent materials and sexting are concerned, elite students are significantly most aware of such dangers. Table 11 gives a summary of the findings of the study.

Table 11: Summary of the findings for across school types

\begin{tabular}{|c|c|c|c|c|}
\hline School & Urban & Suburban & Rural & Elite \\
\hline $\begin{array}{l}\text { 1. Befriending and } \\
\text { meeting strangers }\end{array}$ & $\begin{array}{l}\text { Highly aware of risks } \\
\text { involved }\end{array}$ & $\begin{array}{l}\text { aware of risks } \\
\text { involved }\end{array}$ & $\begin{array}{l}\text { Significantly least } \\
\text { aware of risks } \\
\text { involved }\end{array}$ & $\begin{array}{l}\text { Highly aware of risks } \\
\text { involved }\end{array}$ \\
\hline $\begin{array}{l}\text { 5. Privacy issues } \\
\text { (like revealing } \\
\text { password) }\end{array}$ & Lack of awareness & Lack of awareness & $\begin{array}{l}\text { Lack of } \\
\text { awareness }\end{array}$ & Lack of awareness \\
\hline $\begin{array}{l}\text { 6. Privacy issues } \\
\text { (things posted } \\
\text { cannot be deleted, } \\
\text { not safe to store } \\
\text { data online \& trust } \\
\text { information online) }\end{array}$ & $\begin{array}{l}\text { Aware of danger \& } \\
\text { significantly most } \\
\text { aware that it is not } \\
\text { safe to store data } \\
\text { online but least } \\
\text { aware with regard to } \\
\text { trusting information } \\
\text { online }\end{array}$ & Aware of danger & Aware of danger & $\begin{array}{l}\text { Aware of danger but } \\
\text { significantly lower } \\
\text { awareness with } \\
\text { regard to deleting } \\
\text { pictures online. }\end{array}$ \\
\hline $\begin{array}{l}\text { 7. Remaining } \\
\text { anonymous online }\end{array}$ & $\begin{array}{l}\text { Lack of awareness. } \\
\text { Significantly the least } \\
\text { aware group. }\end{array}$ & Lack of awareness. & $\begin{array}{l}\text { Lack of } \\
\text { awareness. }\end{array}$ & Lack of awareness. \\
\hline 8. Posting of selfies & $\begin{array}{l}\text { More aware of risk } \\
\text { involved }\end{array}$ & $\begin{array}{l}\text { Less aware of risk } \\
\text { involved }\end{array}$ & $\begin{array}{l}\text { More aware of } \\
\text { risk involved }\end{array}$ & $\begin{array}{l}\text { Less aware of risk } \\
\text { involved }\end{array}$ \\
\hline $\begin{array}{l}\text { 9. Harassment \& } \\
\text { cyberbullying }\end{array}$ & $\begin{array}{l}\text { Aware that these are } \\
\text { wrong and indicate } \\
\text { willingness to act if } \\
\text { they witness such } \\
\text { incidents. }\end{array}$ & $\begin{array}{l}\text { Aware that these } \\
\text { are wrong and } \\
\text { indicate willingness } \\
\text { to act if they } \\
\text { witness such } \\
\text { incidents. } \\
\text { Significantly more } \\
\text { willing to act. }\end{array}$ & $\begin{array}{l}\text { Aware that these } \\
\text { are wrong and } \\
\text { indicate } \\
\text { willingness to act } \\
\text { if they witness } \\
\text { such incidents. }\end{array}$ & $\begin{array}{l}\text { Aware that these are } \\
\text { wrong and indicate } \\
\text { willingness to act if } \\
\text { they witness such } \\
\text { incidents. } \\
\text { Significantly more } \\
\text { willing to act. } \\
\text { Significantly more } \\
\text { aware of } \\
\text { consequences of } \\
\text { cyberbullying than all } \\
\text { other school-types. }\end{array}$ \\
\hline
\end{tabular}




\begin{tabular}{|c|c|c|c|c|}
\hline $\begin{array}{l}\text { 10. Sexting (engage } \\
\text { in online sexual } \\
\text { activities or sexual } \\
\text { talk) }\end{array}$ & $\begin{array}{l}\text { Aware of such } \\
\text { dangers }\end{array}$ & $\begin{array}{l}\text { Aware of such } \\
\text { dangers }\end{array}$ & $\begin{array}{l}\text { Aware of such } \\
\text { dangers }\end{array}$ & $\begin{array}{l}\text { Aware of such } \\
\text { dangers. } \\
\text { Significantly most } \\
\text { aware of such } \\
\text { dangers }\end{array}$ \\
\hline $\begin{array}{l}\text { 11. Exposure to } \\
\text { decent materials }\end{array}$ & $\begin{array}{l}\text { Aware of such } \\
\text { dangers }\end{array}$ & $\begin{array}{l}\text { Aware of such } \\
\text { dangers }\end{array}$ & $\begin{array}{l}\text { Aware of such } \\
\text { dangers }\end{array}$ & $\begin{array}{l}\text { Aware of such } \\
\text { dangers. } \\
\text { Significantly most } \\
\text { aware of such } \\
\text { dangers }\end{array}$ \\
\hline
\end{tabular}

\section{DISCUSSION OF FINDINGS}

The discussion will be undertaken in accordance to the research questions.

(a) Are the students from the four schools aware of the risks and dangers of SN?

(b) Are there any differences in awareness among these students?

Generally, students across all school types are aware of the risks and dangers associated with SN particularly students from the elite schools which comprise all female students. Students from the urban and elite schools can be roughly classified as those from urban areas whereas students from the suburban and rural schools can be considered generally as more rural students. This general awareness is a good thing which indicates that there is no rural-urban divide with regard to awareness of such risks. These findings show that students in Malaysia are not very different from those in the western countries (LaRose et al., 2006; Lipford et al., 2008; Strater \& Lipford, 2008; Youn, 2009) in that they are aware of viruses and identity theft and other security issues on SN systems. The findings also concur with that of the 2014 report (Digi Telecommunication, 2014).

However, according to the study "On the use of the Internet by Malaysian youths" (Digi Telecommunication, 2014), it was found that a substantially large number of the students were unable to protect themselves online. This was also evident in this study. Students of all school types lack awareness regarding privacy issues such as the danger of revealing the password to strangers. Students in this study are also not aware that staying anonymous online is not possible. Girls from the elite school seem to be even more oblivious about this issue. They are not wary about posting their personal information and photos online in public profiles such as Facebook and are only concerned about not communicating with strangers. Cox (2007) in his study found similar carelessness among many youths.

Fortunately, all of them are aware that things posted online cannot be deleted and that it is not safe to store information online. However, there seems to be significantly less awareness among urban and elite students regarding the above issues compared to students from other school types. In addition to that, the students of the four schools do not regard selfie postings as dangerous and indulge in it regularly. This is consistent with the research findings of Scott (2016) on a group of Form Five students in the United Kingdom and also consistent with the 2014 report (Digi Telecommunication, 2014).

However, it has to be pointed out that students from urban and rural schools seem more cautious regarding posting selfies or rather they indulge less in this practice compared to elite school and suburban school students. Students in the elite school and suburban school are all Malay whereas the other two schools comprise more non-Malay students, which suggest that posting of selfies are more popular among Malay students. This is quite 
disturbing especially in the case of students from the elite schools as they stay in the school hostel and are generally protected from the outside world, thus they may become victims of online prowlers.

Students in suburban schools and the rural school appear willing to meet strangers they meet online. This is particularly apparent among students in a rural schools. It appears that more Chinese students are willing to meet strangers online than Malay students, which suggests that they are more in danger from such practices than Malay students. They are similar to the $8 \%$ of the teens described by Cox (2007).

On the positive side, it is found that there is also a general awareness among students that harassment and cyberbullying are wrong and the students seem willing to act. The students from the elite school take the consequences of texting and cyberbullying most seriously compared to the students in the other schools. In addition to that, the students from the suburban and elite students are more willing to act compared to the two groups suggesting Malay students are more inclined to act compared to students from other races. Furthermore, elite students seem very aware of the consequences of these activities. This is also not a pattern of the rural-urban divide but more of a racial divide. This pattern is repeated in the case of dangers arising from sexting and exposure to indecent materials. The elite girls are most aware of such dangers compared to those from other schools. This is definitely an improvement from the 2014 report (Digi Telecommunication, 2014) which revealed that very few students would seek help from their teachers, counselors and online public support system.

Finally, in the previous paragraph, it was mentioned that elite students are more exposed to online risks and dangers because they have the tendency to post selfies online. However, their awareness of harassment and cyberbullying and their readiness to act somewhat compensate for this vulnerability. In addition to that, Thang et al. (2016) in her interview with these students found that they are very aware of the negative consequences of texting and very cautious when sending out messages.

\section{IMPLICATIONS AND CONCLUSION}

First, it is proposed that CyberSAFE Malaysia enhances its efforts in educating students, especially female students through more seminars or awareness talks regarding actions to take when they are faced with cyberbullying and online harassment. Students should be made aware that they should act when they are the victims and not only act when they witness such incidents. The "Klik dengan Bijak" programme (2017) should be undertaken in a more proactive and aggressive manner. The vulnerability of the 'protected' girls (i.e. girls from boarding schools) towards SNS calls for more programmes under the "Klik dengan bijak" campaign to support them. It is proposed that efforts should be undertaken to assure that information in the "Klik dengan bijak" webpage and Facebook page are brought to the attention of these girls. It would be extremely useful too if MCMC can get related schools to work with it in carrying out joint programmes and campaigns to educate these students with regard to the dangers and risks of SN. In addition to that the teachers from these schools should attend seminars and initiatives organised by MCMC to further learn of ways to support and protect their students.

Second, parents should also play a role in this. Generally, Malaysian parents have the tendency to be strict on their daughters and lax on their sons as they think that they are not at risk of being cheated or abused. This is not wise and awareness should be brought to 
parents that their sons can be at risk too. This awareness can be achieved by introducing public educational programmes on television and radio. Parents should also be educated on how to exercise parental control by blocking websites promoting pornography, gambling and child sexual-abuse activities.

Third, in addition to aggressively advertising in public communication systems such as television, radio, and newspapers regarding the various forms of abuse of the Internet, MCMC should consider setting up clear social media guidelines for school students. Students should be introduced to these guidelines in an interactive way such as through plays, games and other activities.

Finally, greater awareness should be created among these students regarding services such as Cyber999 and MyCert (Malaysian Computer Emergency Response Team) that they can contact to report computer security and privacy invasion incidences through campaigns through television, radio and road show to schools. Private organisations should also be sought to support such efforts to ease the burden of the Government.

Although the research has reached its aims, there were some unavoidable limitations. There is the possibility of sample selection bias in this study as the target population is only secondary school students from four schools in the Klang Valley and Selangor. There is a possibility that the narrow focus may have limited the generalisability of the results. Another limitation is that there was no way of assuring that the personal information and networking behaviours revealed by users in social networking sites are the absolute truth. There is a possibility some students might have given inaccurate information. False information could affect the reliability of the findings. This is a problem that is unavoidable in any research, but through the use of rigorous statistics, it is hoped that this problem has been minimised.

Despite the limitations, it is possible to conclude that the findings of the study have provided deeper insights into Malaysian students' behaviours, thoughts, and beliefs regarding SN which will go a long way in helping teachers, parents, and policymakers come up with better monitoring and protective measures to safeguard and protect Malaysian students.

\section{ACKNOWLEDGEMENT}

This paper was part of a research project (Code SK-2015-003) funded by the Malaysian Communications and Multimedia Commission (MCMC).

\section{BIODATA}

Dr. Thang Siew Ming is a Professor at ELM Graduate School, HELP University, Kuala Lumpur. Her areas of interest are CALL, Learner Autonomy, Motivation, and Eye-tracking research. Email: siewming.t@help.edu.my

Dr. Lay Shi $\mathrm{Ng}$ is an experienced lecturer in teaching Chinese Mandarin as Second Language. Her area of expertise is in Chinese syntax. Her current research interests include Chinese grammaticalisation, CALL and MALL. Email: lizng@ukm.edu.my

Dr. Adzuhaidah M. Taha is a senior English language teacher at Sekolah Seri Puteri Cyberjaya. Her areas of interest are CALL, Motivation and Language Learning Strategies. Now she's currently into research pertaining to Online Social Networking among teenagers. Email: adzu@seriputeri.edu.my 


\section{REFERENCES}

Balakrishnan, V. (2015). Cyberbullying among young adults in Malaysia: The roles of gender, age and internet frequency. Computers in Human Behavior, 46, 149-157.

Berkman, R. I., \& Shumway, C. A. (2003). Digital dilemmas: Ethical issues for online media professionals. Ames, IA: lowa State Press, 386.

Bonneau, J., \& Preibusch, S. (2010). The password thicket: Technical and market failures in human authentication on the web. The Ninth Workshop on the Economics of Information Security (WEIS 2010).

Boyd, D. M., \& Ellison, N. B. (2007). Social network sites: Definition, history, and scholarship. Journal of Computer-Mediated Communication, 13(1), 210-230. doi: 10.1111/j.10836101.2007.00393.x

Cocking, D., \& Matthews, S. (2000). Unreal friends. Ethics and Information Technology, 2(4), 223-231.

Cox Communications. (2007). Research findings: Cox teen Internet safety study wave II. Retrieved from http://www.cox.com/wcm/en/aboutus/datasheet/takecharge/archives/2007-teensurvey.pdf?campcode=takecharge\%20\%20\%20-archive-link_2007 survey_0511, June 14, 2016.

Cowie, H. (2013). Cyberbullying and its impact on young people's emotional health and wellbeing. The Psychiatrist, 37, 167-170.

Davidson, J., \& Gottschalk, P. (2010). International policy and legislation. In J. Davidson \& P. Gottschalk (Eds.), Internet child abuse: Current research, policy and police practice. London: Routledge.

Debatin, B., Lovejoy, J. P., Horn, A., \& Hughes, B. N. (2009). Facebook and online privacy: Attitudes, behaviors, and unintended consequences. Journal of Computer-Mediated Communication, 15, 83-108.

Digi Telecommunication. (2014). CyberSAFE in schools: A national survey report 2014. The Malaysian Ministry of Education in collaboration with DiGI Telecommunications, Malaysian Communications and Multimedia Commission (MCMC) and Cyber Security Malaysia.

Hinduja, S., \& Patchin, J. W. (2010). Bullying, cyberbullying, and suicide. Archives of Suicide Research, 14(3), 206-221.

lachello, G., \& Hong, J. (2007). End-user privacy in human-computer interaction. Foundations and Trends in Human-Computer Interaction, 1(1), 1-137. Klik dengan Bijak. Retrieved from https://www.facebook.com/klikdenganbijak/December 27, 2017.

Klik dengan Bijak. Retrieved on December 27, 2017, from http://www.klikdenganbijak.my/Galleries/Tips/Detail-BuliSiber.aspx

Krish, P., Hussin, S., Sivapuniam, N. (2011). Language learning and language acqulsition in online forums. 3L: The Southeast Asian Journal, 17(2), 91-100.

LaRose, R., Rifon, N. J., \& Enbody, R. (2006). Promoting personal responsibility for Internet safety. Communication of the ACM, 51(3), 71-76.

Lenhart, A. (2009). Teens and sexting: How and why minor teens are sending sexually suggestive nude or nearly nude images via text messaging. Retrieved on June 14, 2016, from http://pewresearch.org/assets/pdf/teens-and-sexting.pdf 
Lenhart, A., Ling, R., Campbell, S., \& Purcell, K. (2010). Teens \& mobile phones. Pew Internet \& American Life Project. Retrieved on June 14, 2016, from http://www.pewinternet.org/Reports/2010/Teens-and-Mobile-Phones.aspx

Lipford, H. R., Besmer, A., \& Watson, J. (2008). Understanding privacy settings in Facebook with an audience view. In Proceedings of the 1st Conference on Usability, Psychology and Security (UPSEC'08) (paper no.2). Berkeley C.A, U.S.A: USENIX Association.

Livingstone, S., \& Bober, M. (2004). UK children go online: Surveying the experiences of young people and their parents. London School of Economics and Political Science, $15-21$.

Lohmann, R. C. (2012). The dangers of teen sexting - Sexting a problem with major consequences. Psychology Today, posted Jul 20, 2012. Retrieved on December 10, 2017, from https://www.psychologytoday.com/blog/teen-angst/201207/thedangers-teen-sexting

Mitchell, K. J., Jones, L., Finkelhor, D., \& Wolak, J. (2014). Trends in unwanted sexual solicitations: Findings from the Youth Internet Safety studies. Retrieved on 19 December, 2017, from http://unh.edu/ccrc/pdf/Sexual\%20Solicitation\%201\%20of\%204\%20YISS\%20Bulleti ns\%20Feb\%202014.pdf

National Campaign to Prevent Teen and Unplanned Pregnancy. (2008). Sex and tech: Results from a survey of teens and young adults. Retrieved on June 14, 2016, from http://www.thenationalcampaign.org/sextech/pdf/sextech_summary.pdf

Ng, L. S., Thang, S. M., \& Noorizah Mohd. Noor (2018). The usage of social networking sites for informal learning: A comparative study between Malaysian students of different genders and age groups, International Journal of Computer Assisted Language Learning and Teaching (IJCALLT), 8(4).

Noor Azlin Bidin \& Normah Mustaffa. (2012). Blogosphere: How youth perceived blogs credibility. Jurnal Komunikasi: Malaysian Journal of Communication, 28(1), 33-54.

Noor Ismawati Jaafar, Bobby Darmawan, \& Mohd Yahya Mohamed Ariffin. (2018) Social Networking Site Adoption in Malaysia and Indonesia. Jurnal Komunikasi: Malaysian Journal of Communication, 34(1), 115-134.

O'Keefe, G. S., \& Clarke-Pearson, K. (2011). The impact of social media on children, Adolescents and families. Pediatrics, 127(4), 800-804. Retrieved on November 25, 2016, from http://pediatrics.aappublications.org/content/127/4/800.full

Sarina Yusuf, Md. Salleh Hj. Hassan, \& Adam Kolo Mohammed Mohammed Ibrahim. (2018). Cyberbullying among Malaysian children based on research evidence. In M. KhosrowPour (Ed.), Encyclopedia of information science and technology (4th ed., pp. 17041722). Hershey: IGI Global.

Schenk A. M., \& Fremouw W. J. (2012). Prevalence, psychological impact, and coping of cyberbully victims among college students. J School Violence, 11, 21-37.

Scott, J. (2016). Children and the Internet: An exploration of Year 5 pupils' online experiences and perceptions of risk. Journal of Huddersfield Student Research, 1-10.

Smith, P., Mahdavi, J. Carvalho, M., \& Tippet, N. (2006). An investigation into cyberbullying, its forms, awareness and impact, and the relationship between age and gender in cyberbullying. Research Brief No. RBX03-06. 
Statista.com. (2019). Active social media users as percentage of the total population in Malaysia from 2016 to 2019. Retrieved on June 2019, from https://www.statista.com/statistics/883712/malaysia-social-media-penetration/

Strassberg, D. S., McKinnon, R. K., Sustaita, M. A., \& Rullo, J. (2013). Sexting by high school students: An exploratory and descriptive study. Archives of Sexual Behaviour, 42(1), 15-21.

Strater, K., \& Lipford, H. R. (2008). Strategies and struggles with privacy in an online SN community. In Proceedings of the 22nd British $\mathrm{HCl}$ Group Annual Conference on People and Computers: Culture, Creativity, Interaction (BCS-HCl '08), pp. 111-119.

Tavani, H. T., \& Grodzinsky, F. S. (2002). Cyberstalking, personal privacy and moral responsibility. Ethics and Information Technology, 4(2), 123-132.

Thang, S. M., Noorizah Mohd. Noor, Azuhaidah M. Taha, Ng, L. S., \& Noor Baizura Abdul Aziz (2016). Effects of social networking on Malaysian secondary school students: Attitudes, behaviours and awareness of risks. Pertanika Journal of Social Sciences \& Humanities, 24(5), 157-168.

Thang, S. M., \& Ng, L. S. (2020). Influence of age groups and school types on informal learning through the use of Social Networking sites. In Zou, B. \& Thomas M. (Eds.), Recent developments in technology - Enhanced and computer-assisted language learning (pp. 30-47). Hershey, PA: IGI Global Publishing.

Toktam Namayandeh Joorabchi, Md. Salleh Hj Hassan \& Mohd. Nizam Osman. (2013). Relationship between Internet usage and positive youth development in Malaysia. Search: The Journal of the South East Asia Research Centre for Communications and Humanities, 5(2), 37-64.

Wolak, J., Mitchell, K., \& Finkelhor, D. (2006). Online victimization of youth, five years later. Retrieved on June 14, 2016 from http://www.missingkids.com/en_US/publications/NC167.pdf

Wolak, J., Finkelhor, D., Mitchell, K. J., \& Ybarra, M. L. (2008). Online "predators" and their victims: Myths, realities, and implications for prevention and treatment. American Psychologist, 63, $111-128$.

Youn, S. (2009). Determinants of online privacy concern and its influence on privacy protection behaviors among young adolescents. The Journal of Consumer Afairs, 43(3), 389. 